\title{
Physico-biochemical and molecular responses of Acacia auriculiformis to
}

\section{salinity stress}

Deepak B. Gupta ${ }^{1}$, Joydeep Banerjee ${ }^{2}$, Krishnendu Pramanik ${ }^{3}$, Arpita Das $^{4}$ and Srikumar Pal ${ }^{1 *}$

${ }^{1}$ Agricultural Biochemistry, Bidhan Chandra Krishi Viswavidyalaya, Mohanpur, Nadia, West Bengal-

741252 , India

${ }^{2}$ Agricultural and Food Engineering Department, Indian Institute of Technology Kharagpur, Kharagpur, Paschim Midnapore, West Bengal-721302, India

${ }^{3}$ Agricultural Biotechnology, Bidhan Chandra Krishi Viswavidyalaya, Mohanpur, Nadia, West Bengal741252 , India

${ }^{4}$ Genetics \& Plant Breeding, Bidhan Chandra Krishi Viswavidyalaya, Mohanpur, Nadia, West Bengal741252, India

Corresponding Author: spal59@rediffmail.com

3

Abstract

Salinity limits the growth and yield of many crops across the globe and is considered as major threat to agriculture. Acacia auriculiformis, an important salt tolerant crop, is growing abundantly in the salt-affected mangrove areas of Sunderban, West Bengal, India. In the present study, we have reported the physiological, molecular and antioxidant response of this crop to a gradient of salt treatments ranging between 0 and $800 \mathrm{mM} \mathrm{NaCl}$. As a stress response, the antioxidant enzymes viz. superoxide dismutase (SOD), catalase (CAT) and guaiacol peroxidase (GPX) were highly activated at 200, 400 and $800 \mathrm{mM} \mathrm{NaCl}$ respectively. Antioxidant metabolites such as phenols and thiols elevated with increasing salt treatments thus augmenting antioxidant activity with significant positive relationship with phenol content. Similarly, phenylalanine ammonia lyase (PAL) activity was up-regulated in a dose dependent manner with significant relationship with phenol content. This study also reported the phenolic 
25 profile for the first time in A. auriculiformis with the abundance of flavonoids. In addition, transcriptional up-regulation of $\mathrm{Na}^{+} / \mathrm{H}^{+}$antiporter gene $(\mathrm{NHX1})$ and the development of robust vascular tissues was noticed at $400 \mathrm{mM} \mathrm{NaCl}$ stress compared to control, while further stress at

$28800 \mathrm{mM} \mathrm{NaCl}$ induced poor vascular tissue growth but with higher PAL activity and consequent higher phenol content. Based on this observation, a model for salt tolerance mechanism of $A$. auriculiformis has been proposed.

Keywords: Acacia auriculiformis, antiporter, antioxidants, cellular anatomy, salt stress.

Salinity is known to severely affect the growth and yield of many crops in arid and semi-arid areas of the world covering approximately $20 \%$ global cultivated land [1]. Salt stress, in general, causes both hyperionic and hyperosmotic effects in plants, eventually leading to disruption of ion homeostasis, membrane disorganization, excess generation of reactive oxygen species (ROS), which may accelerate stress-induced oxidative damage of biological macromolecules and cellular structure [2]. In addition, salinity with its effect on stomatal closure reduces the carbon dioxide/ oxygen ratio in leaf tissues and limits carbon dioxide assimilation [3]. The major ROS include superoxide radical anion $\left(\mathrm{O}_{2}^{-}\right)$, hydrogen peroxide $\left(\mathrm{H}_{2} \mathrm{O}_{2}\right)$, hydroxyl radical $(\mathrm{OH})$ and singlet oxygen $\left({ }^{1} \mathrm{O}_{2}\right)$, which are usually produced at the

42 reaction centers of photosystem I and II (PS I and PS II) in chloroplast [4]. In particular, $\mathrm{O}_{2}^{-}$is generated by the non-cyclic electron transport, when stress conditions favours accumulation of

44 nicotinamide adenine dinucleotide phosphate (NADPH) and limit $\mathrm{CO}_{2}$ assimilation [5].

45 Subsequently, $\mathrm{O}_{2}^{-}$is converted to hydrogen peroxide $\left(\mathrm{H}_{2} \mathrm{O}_{2}\right)$ through dismutation reaction 46 catalyzed by SOD and finally to highly oxidizing hydroxyl radical (OH) through Fenton 
47 reaction [6]. Plants have evolved a well defined but complex antioxidant system consisting of enzymatic antioxidants such as SOD, CAT, specific and non-specific peroxidases, glutathione reductase (GR) and metabolites viz. ascorbate, glutathione and phenolic compounds [6,7].

50 Among these metabolites, phenolic compounds are widespread in plant kingdom and their

51 accumulation is considered as a self-protection way to strengthen ROS scavenging capacity in

52 plants for alleviating salt induced oxidative stress $[8,9,10]$. Indeed, the enhanced accumulation

53 of phenolic compounds under different environmental stresses triggers upregulation of PAL,

54 the key enzyme of phenol synthesis [11]. Thus, plants under salinity stress can serve as

55 potential source of phenolic compounds with restricted biomass production. Moreover, several

56 plants have evolved diverse anatomical, physiological, biochemical and molecular

57 mechanisms [12], which allow them either to sustain or limit their growth under stressed

58 condition. Halophytes usually overcome salt stress either by removing the cytosolic $\mathrm{Na}^{+}$load

59 by way of transporting it into vacuole via $\mathrm{Na}^{+} / \mathrm{H}^{+}$antiporter [13] or by accumulating enhanced

60 level of osmo-protectants [14].

61 Acacia auriculiformis, a representative member of Fabaceae, is reputed for its use as fodder

62 and textile industry because of its high tannin content. Moreover, this crop has the potential to

63 find its place in social forestry and cropland agroforestry because of its fast growing nature

64 and wide adaptability to diverse environmental conditions [15]. In West Bengal, India, this

65 crop is grown abundantly in costal salt-affected region of Sunderban and exhibits a high

66 degree of salt tolerance. The underlying salt tolerance mechanism of this crop is reported to be

67 closely associated with ion selectivity, increased accumulation of osmoprotectants, 
mechanism $[14,16]$. However, antioxidant metabolism in response to salinity stress in $A$. auriculiformis is ambiguous and not well documented.

71 Therefore, the present study was extended to examine the activities of antioxidant enzymes viz.

72 SOD, CAT, GPX and PAL in response to a gradient of salinity stress, ranging from 0 to 800

$73 \mathrm{mM} \mathrm{NaCl}$. Moreover, total phenol content with its profile of phenolic compounds and

74 associated antioxidant activity were also explored. Salt induced physiological changes such as

75 cross-linking of cell wall components and vascular tissue development through histological

76 staining have also been noticed. Additionally, gene expression of $\mathrm{Na}^{+} / \mathrm{H}^{+}$-antiportes in $A$.

77 auriculiformis at $400 \mathrm{mM}$ has been reported.

Materials and Methods

Salinity treatment and morphological study

80 The three month-old seedlings of A. auriculiformis, collected from salt affected areas of

81 Sunderban, South 24 Parganas, West Bengal, India and grown in sandy-clay soil in pots $(25 \mathrm{~cm}$

82 diameter $\times 20 \mathrm{~cm}$ height) in three replicates at the University green house at Mohanpur, Nadia,

83 West Bengal and treated each with 0, 200, 400, 600 and $800 \mathrm{mM} \mathrm{Nacl}$ for consecutive 10 days.

84 The growth pattern was analyzed. For biochemical studies, the leaves from each treatment

85 replications were harvested and preserved at $(-) 80^{\circ} \mathrm{C}$ until further use.

86 Assay of antioxidant enzymes

87 All extraction steps were carried out at $4^{\circ} \mathrm{C}$ and SOD and CAT were analyzed based on standard protocol [17]. SOD (EC 1.15.1.1) was extracted in $50 \mathrm{mM}$ phosphate buffer (pH 7.8) containing $2 \%$ PVP and $0.25 \%$ Triton-X. SOD was assayed in $50 \mathrm{mM}$ phosphate buffer (pH 7.8), $20 \mu \mathrm{M}$ methionine, $1.12 \mu \mathrm{M}$ nitroblue tetrazolium (NBT), $1.5 \mu \mathrm{M}$ EDTA and $75 \mu \mathrm{M}$ riboflavin using 
the photochemical NBT method in terms of SOD's ability to inhibit reduction of NBT to form formazon by superoxide. The photoreduction of NBT was measured at $560 \mathrm{~nm}$. The SOD activity was expressed in units, which were defined as amount of sample required to cause $50 \%$ inhibition of photo-reduction of NBT per minute. CAT (EC 1.11.1.6) and GPX (EC 1.11.1.7) were extracted in $100 \mathrm{mM}$ phosphate buffer ( $\mathrm{pH} 7.5)$ containing $2 \%$ PVP and $0.25 \%$ Triton-X. CAT was evaluated spectrophotometrically by determining the consumption of $\mathrm{H}_{2} \mathrm{O}_{2}$ at $240 \mathrm{~nm}$ in $100 \mathrm{mM}$ phosphate buffer $(\mathrm{pH} 7.5)$ and $200 \mathrm{mM} \mathrm{H}_{2} \mathrm{O}_{2}$. CAT activity was expressed as $\mu \mathrm{mol}$ of $\mathrm{H}_{2} \mathrm{O}_{2}$ destroyed /g/ min. GPX was assayed in $100 \mathrm{mM}$ phosphate buffer (pH 7.5), $30 \mathrm{mM}$ $\mathrm{H}_{2} \mathrm{O}_{2}$ and $2 \mathrm{mM}$ guiaicol. The absorption at $470 \mathrm{~nm}$ was recorded and the activity was calculated using the extinction coefficient of $26.6 \mathrm{mM}^{-1} \mathrm{~cm}^{-1}$. GPX activity was expressed as $\mu \mathrm{mol}$ of guiaicol oxidized/ g / min. PAL (EC 4.3.1.5) was extracted in $100 \mathrm{mM}$ phosphate buffer, $\mathrm{pH} 7.5$ containing 2\% PVP and $0.25 \%$ Triton-X [18]. The enzyme was examined spectrophotometrically by the formation of $t$-cinnamic acid at $270 \mathrm{~nm}$ in $1.9 \mathrm{ml}$ of $100 \mathrm{mM}$ Tris-HCl buffer $(\mathrm{pH} 8.8)$ and $10 \mathrm{mM}$ phenylalanine. PAL activity is expressed as $\mu \mathrm{mol}$ of $t$-cinnamic acid formed $/ \mathrm{g} / \mathrm{min}$.

\section{Analysis of total phenol, phenolic compounds and total thiol}

Total phenol was extracted after boiling at $90^{\circ} \mathrm{C}$ for $2 \mathrm{~h}$ with $1.2 \mathrm{M} \mathrm{HCl}$ in $50 \%$ aqueous methanol [19]. The supernatant obtained after centrifugation was filtered through Whatman 42 filter paper. Total phenol content was determined using Folin-Ciocalteau Reagent (FCR) and expressed as mg gallic acid equivalent per gram dry weight (mg GAE/g DW). For the analysis of phenolic compounds by HPLC, the extract was further filtered through syringe filter $(0.22 \mathrm{~mm}$ nylon syringe filters; Phenomenex, Torrance, CA, USA). The separation of phenolic compounds was performed in a HPLC (Agilent 1220) coupled with C-18 RP column (125/4 mm with $5 \mathrm{~mm}$ particle size), PDA detector (WL $280 \mathrm{~nm}$ ). The mobile phase consisting of solvent A (1\% formic 
114 acid in water) and solvent B (1\% formic acid in acetonitrile) was used at a flow of $1 \mathrm{ml} / \mathrm{min}$ with

115 the following gradient program: 15\% B linear from 0 to $12 \mathrm{~min}$.; $50 \% \mathrm{~B}$ linear from 12 to 35

116 min.; 85\% B linear from 35 to $45 \mathrm{~min}$; 15\% B linear from 45 to $50 \mathrm{~min}$. The column

117 temperature was maintained at $35^{\circ} \mathrm{C}$. The sample $(20 \mu \mathrm{L})$ was injected in duplicate. The

118 chromatographic peaks were identified based on comparison of retention time with those of

119 authentic analytical standards. The quantitative analysis of phenolic compounds was made by

120 chromatographic chemistation software [20] using a linear regression for the relationship of peak

121 area versus concentration of phenolic compound.

122 Total thiol was extracted in $20 \mathrm{mM}$ EDTA and measured [21] at $412 \mathrm{~nm}$ in a reaction mixture

123 consisting of sample extract, $200 \mathrm{mM}$ Tris-HCl buffer (pH 8.O), and $10 \mathrm{mM}$ DTNB following

124 incubation for 15 minutes at room temperature. Total thiol was expressed as $\mu$ mol of GSH per

125 gram fresh weight of sample ( $\mu \mathrm{mol} \mathrm{GSH} / \mathrm{g} \mathrm{FW})$.

126 Analysis of antioxidant activity

127 The antioxidant activity of the phenol extract was determined according to earlier reported

128 protocol [22]. In 1,1-diphenyl-2-pycrylhydrazyl (DPPH) assay, the changes in absorbance was

129 measured at $517 \mathrm{~nm}$ in reaction mixture containing $150 \mu \mathrm{l}$ of phenolic extract and $2850 \mu \mathrm{l}$ of

$130 \quad 0.004 \%$ DPPH while that in Ferric Reducing Antioxidant Power (FRAP) assay was recorded at

$131593 \mathrm{~nm}$ in reaction mixture consisting of $150 \mu 1$ neutralized sample extract and $2850 \mu 1$ FRAP

132 reagent. The antioxidant activity was expressed as $\mathrm{mg}$ trolox equivalent per gram dry weight (mg

$133 \mathrm{TE} / \mathrm{g} \mathrm{DW})$.

134 Analysis of NHX1 gene expression in A. auriculiformis

135 Transcript level expression study of $\mathrm{Na}^{+} / \mathrm{H}^{+}$antiporter $(\mathrm{NHX1})$ in A. auriculiformis was carried

136 out considering the forward primer (NHX1F; 5'-TTTGGCAGGCACTCAACAGA-3') and 
137

138

139

140

141

142

143

144

145

146

147

148

149

150

151

152

153

154

155

156

157

158

159

reverse primer (NHX1R; 5'-TAAGGAGTCCTGCCCCTCTC-3') in semi-quantitative reverse transcriptase PCR using total RNA isolated from leaf tissue of control and $400 \mathrm{mM} \mathrm{NaCl}$ treated plants at same developmental stages. Actin gene specific primer (ActF; 5'GTGCCCATTTACGAAGGATA-3' and ActR; 5'-GAAGACTCCATGCCGATCAT-3') were used as endogenous loading control.

\section{Pholoroglucinol Staining}

The transverse section of freshly harvested phyllode, obtained from previously treated $A$. auriculiformis with 0, 400 and $800 \mathrm{mM} \mathrm{Nacl}$ was subjected to phloroglucinol staining following the protocol reported earlier [23].

\section{Statistical analysis}

Experimental results were expressed as means \pm SD considering three replicates for all the measurements. The data were analyzed by an analysis of variance $(p<0.05)$ and significant differences among the treatments were tested by Duncan's multiple range test at $5 \%$ level using Statistical Tool for Agricultural Research (STAR) software package version 2.0.1 of International Rice Research Institute (IRRI). Correlation coefficients (r) were also calculated between antioxidant activity and phenol content.

\section{Results}

\section{Effect of salt stress on SOD, CAT, GPX and PAL}

Salt treatments significantly enhanced SOD activity (Fig. 1A) over control at 200 and $400 \mathrm{mM}$ $\mathrm{NaCl}$, but the stimulatory effect was more pronounced at $400 \mathrm{mM}$. On the contrary, at 600 and $800 \mathrm{mM}$ salt treatment, SOD activity declined significantly below control. Hence, the SOD activity might be either up-regulated or down-regulated depending on the severity of stress. The result however, suggested that relatively higher $\mathrm{H}_{2} \mathrm{O}_{2}$ generation was imposed at lower (200 and 
$400 \mathrm{mM}$ ) than higher (600 and $800 \mathrm{mM}$ ) salt concentration. The CAT activity (Fig. 1B), on the other hand, increased significantly over control with all the treatments except $400 \mathrm{mM}$. It was further noticed that PAL (Fig. 1C) activity and GPX activity (Fig. 2A), the key enzymes of phenol synthesis and oxidation respectively, controlling the phenol accumulation in plants, increased significantly over control in response to increasing salt treatments.

\section{Effect of salt treatment on content of phenolic compounds and reduced glutathione:}

Total phenol content (Fig. 2B) increased significantly over control with increasing level of salt treatments. Similar to phenol, total thiol content increased significantly with increasing salinity (Fig. 2C). In the present study an attempt has been made for analysis of 16 phenolic compounds (Fig. 3) consisting of 4 hydroxybenzoic acids viz. gallic (Gal), protocatechuic (Pro), phydroxybenzoic (Pba) and vanillic acid (Van), 5 hydroxycinnamic acids viz. p-comaric (Pco), caffeic (Caf), ferulic (Fer), cinnamic (Cin) and chlorogenic acid (Chl) and 7 flavonoids viz. myricetin (Myr), apigenin (Api), quercetin (Qur), catechin (Cat), luteolin (Lut) Rutin (Rut) and kaemferol (Kam). However, our study documented the detection of 15 phenolic compounds in $A$. acquiformis (Table 1). The flavonoids formed the major class of phenolic compounds followed by hydroxybenzoic acid representing 66.55 and $27.34 \%$ respectively of total phenolic compounds. Among the phenolic compounds, catechin was observed as most abundant forming $51.17 \%$ of total phenolic compounds and its content increased significantly in a dose dependent manner. Gallic acid ranked distinct second representing nearly $16 \%$ of total phenolic compounds. Salt treatment with 200 and $400 \mathrm{mM} \mathrm{NaCl}$ did not produce any significant differences in gallic acid content with the control. However, gallic acid content at 600 and $800 \mathrm{mM}$ has found to differ significantly not only between them but also from other treatments. Protocatechuic acid with its share of $6.28 \%$ formed the third major phenolic compound and increased significantly at 
Differential salt stress depicted anatomical changes in A. auriculiformis (Fig. 5B).

higher treatments $(600$ and $800 \mathrm{mM})$. The next abundant compound was chlorogenic acid, an ester of caffeic and quinic acid and increased significantly with increasing salt treatments. The phenolic compound detected as minor included p-hydroxybenzoic, caffeic, p-coumaric ferulic and cinnamic acid. The mean of vanillic acid and other flavonoids together formed $19.12 \%$ of total phenolic compound.

\section{Effect of salt treatment on antioxidant activity:}

The antioxidant activity, measured under DPPH and FRAP assay (Fig. 4), was significantly increased over control with increasing salt treatments. However, the antioxidant activity measured under DPPH assay produced a greater absolute value than that obtained from FRAP assay. This difference indicated that phenolic compounds occurring in A. auriculiformis scavenged ROS chiefly by hydrogen atom transfer (HAT) rather than single electron transfer (SET) mechanism. The antioxidant activity showed a significant and positive relationship with phenol in DPPH $(r=0.73)$ and in FRAP assay $(r=0.71)$.

\section{Salt stress induced physiological, anatomical and gene expressional changes}

Application of salt treatment at varying concentration resulted in differential physiological response (Fig. 5A). In untreated control, more number of leaves occasionally in one branch was noticed after 10 days, while the number of leaves declined with increasing salt treatment except at $800 \mathrm{mM} \mathrm{NaCl}$ where, appearance of new leaves was noticed. Moreover, some curled leaves were also detected at $600 \mathrm{mM} \mathrm{NaCl}$, while $800 \mathrm{mM}$ salt treatment resulted in almost curved leaves. Morphological study clearly demonstrated that dry matter accumulation in seedling of $A$. auriculiformis decreased with increasing salt treatment.

Pholoroglucinol staining documented significant changes in vascular tissues across different 
treatments. Pholoroglucinol staining established more cross-linking of cell wall components with $400 \mathrm{mM} \mathrm{NaCl}$ but less with $800 \mathrm{mM} \mathrm{NaCl}$ treated phyllode over control. In addition, $400 \mathrm{mM}$ $\mathrm{NaCl}$ stressed phyllode exhibited better vascular tissue development as opposed to $800 \mathrm{mM}$ $\mathrm{NaCl}$ stressed condition and even better over control. Additionally, the phloem tissue development in the phallode was found to increase in the order of $800 \mathrm{mM}<$ control $<400 \mathrm{mM}$ $\mathrm{NaCl}$ treated seedlings. As $400 \mathrm{mM} \mathrm{NaCl}$ treatment depicted more cross-linking in seedling compared to control as well as $800 \mathrm{mM} \mathrm{NaCl}$ treatment, the transcript expression of a $\mathrm{Na}^{+} / \mathrm{H}^{+}$ antiporters gene $(\mathrm{NHX1})$ was analyzed in $400 \mathrm{mM} \mathrm{NaCl}$ treated seedlings. Relative transcript abundance of $N H X 1$ gene was found to be up regulated at $400 \mathrm{mM} \mathrm{NaCl}$ stress compared to untreated control plants (Fig. 5C). Quantification of relative expression of $\mathrm{Na}^{+} / \mathrm{H}^{+}$antiporters (relative to Actin) conducted through imajej software analysis revealed that upon $400 \mathrm{mM} \mathrm{NaCl}$ stress the gene was 2.84 fold up-regulated compared to control plants (Fig. 5D).

\section{Discussion:}

All plants under suboptimal environmental condition, facing abiotic stress, experience an imbalance between the energy received and the ability to process it. ROS formation, photoinhibition and growth reduction are the major consequences of such energy imbalances [24,25]. In the present study, decline in number of leaves observed with increasing salinity suggested that the growth reduction appears to be related to impairment of either non-cyclic photosynthetic electron transport or $\mathrm{CO}_{2}$ assimilation. Earlier study reported that the growth related parameters including stomatal conductance, photosynthetic pigments, protein and carbohydrate content in $A$. auriculiformis were adversely affected by salinity in a time and dose dependent manner [14]. Although, measurement of MDA content serves as an indicator of ROS mediated oxidative injury in plant cells, the differential stimulation of SOD and CAT activity to the severity of salt 
stress provides an indirect evidence of generation of ROS. In the present study comparison of SOD and CAT activity across different salt treatments, provided a clue to greater accumulation of $\mathrm{H}_{2} \mathrm{O}_{2}$ at $400 \mathrm{mM}$, which was also evidenced by higher SOD and moderate CAT activity. Similar activation of SOD was noticed at $400 \mathrm{mM}$ in a halophyte, Bruguiera pariflora, growing abundantly in salt affected areas of Sunderban, West Bengal, India [26]. On the contrary, the moderate SOD and higher CAT activity at $800 \mathrm{mM}$ resulted in lower concentration of $\mathrm{H}_{2} \mathrm{O}_{2}$. Relatively lower SOD activity at higher salt stress was similar to the previous report in shoot tissues of Brassica napus L [27]. In rice, it was observed that SOD activity was decreased at higher salt concentration in sensitive rice genotypes in contrast to stimulatory effect at lower concentration in tolerant genotypes [28]. Similar increase in CAT activity was also reported for salt-tolerant cotton [29].

In the present study, the enhanced GPX activity with increasing salinity was corroborated with previous reports in rice [30] and other plants [31,32]. The enhanced GPX activity, which uses $\mathrm{H}_{2} \mathrm{O}_{2}$ as a substrate for oxidation of phenolic compounds further reduced the $\mathrm{H}_{2} \mathrm{O}_{2}$ concentration at $800 \mathrm{mM}$. Thus, it appeared reasonable to assume that the most toxic ROS, the $\mathrm{OH}^{-}$, is formed via Fenton-like reaction, in greater abundance at 400 than $800 \mathrm{mM} \mathrm{NaCl}$. Consequently, ROS generation in $A$. auriculiformis in response to salt treatment revealed higher with $400 \mathrm{mM}$ than $800 \mathrm{mM} \mathrm{NaCl}$. Moreover, higher thiol content at $800 \mathrm{mM}$ than $400 \mathrm{mM}$ salt stress further reduced the ROS load at $800 \mathrm{mM}$ as these compounds were reported to scavenge ROS in vivo. Moreover, total thiol primarily comprises of reduced GSH, a major component of thiol compounds act as a substrate for glutathione peroxidase and thus reduces the $\mathrm{H}_{2} \mathrm{O}_{2}$ load in cell. In general, environmental stresses and elicitor are known to modulate the phenolic compounds in plants $[33,34]$ and changes in these compounds are critically associated with salt sensitivity of 
252 plant as well as severity of salt stress [35,36]. They traditionally appear in leaves with obvious

253 oxidative stress. Therefore, leaves of $A$. auriculiformis upon exposure to $400 \mathrm{mM} \mathrm{NaCl} \mathrm{stress}$

254 should accumulate greater phenol. By contrast, leaf treated with $800 \mathrm{mM} \mathrm{NaCl}$ and with

255 consequent lower $\mathrm{OH}$ radical concentration, displayed significantly higher PAL activity, phenol

256 concentration and in vitro antioxidant activity. In corroboration with the previous report, it

257 disclosed that inhibition of $\mathrm{CO}_{2}$ assimilation at $800 \mathrm{mM}$ salt stress resulted greater NADPH

258 accumulation through linear photosynthetic electron transport, which is reversed by the

259 consumption of NADPH for phenol synthesis [14]. Similar to our finding, salinity induced

260 enhanced accumulation of phenol has been observed in radish [37], pepper [38], honeysuckle

261 [39] and Cakile maritima [40]. Moreover, higher in vitro antioxidant activity associated with

262 higher phenol concentration, though compared well with the earlier reports [40] had hardly any

263 chance to scavenge ROS in vivo in absence of oxidative stress [36,41]. The higher accumulation

264 of phenolic compounds with increasing salinity, flavonoids in particular, act as energy escape

265 valve rather than antioxidant function, to dissipate excess excitation energy resulting from

266 salinity stress [42]. With increasing salinity, the higher accumulation of phenolic compounds,

267 flavonoids in particular, with their role in energy dissipation and carbon diversion, act as energy

268 escape valve rather than antioxidant function [42].

269 Overproduction of $\mathrm{H}_{2} \mathrm{O}_{2}$ at $400 \mathrm{mM}$ generated not only ample $\mathrm{OH}$ radical concentration but also

270 lignin precursor through GPX reaction. All these events, in turn, facilitated ROS mediated cross-

271 linking in cell wall polymeric components and support our observation of phloroglucinol

272 staining. In corroboration to our present findings, earlier study documented that strong vascular

273 tissue development is helpful for the seedlings to withstand salt stress in a better manner [43].

274 The antioxidant response at $400 \mathrm{mM} \mathrm{NaCl}$ thus improved the cell wall integrity and membrane 
275 permeability that might lead to greater accumulation of $\mathrm{Na}^{+}$in cytosol. However, the over expression of $\mathrm{NHX1}$ gene at $400 \mathrm{mM}$ was triggered to reduce cytosolic $\mathrm{Na}$ concentration by

277 allowing its transportation into vacuole. Similar to our finding, salinity induced up-regulation of

278 transcription of $N H X 1$ gene in several tree species including Populus euphortica and Aluropus

279 littoralis has been reported [44]. In contrast, antioxidant response with higher phenol

280 accumulation with its role in photoprotection provided a back-up defense at $800 \mathrm{mM}$.

281 Based on our finding, a plausible model for salt tolerance in A. auriculiformis has been proposed

282 (Fig. 6). In addition to adverse effect on the growth depending on the severity of stress, central

283 to this model was the activation of SOD and PAL. At $400 \mathrm{mM}$, higher activation of SOD 284 accompanied by moderate CAT activity was the probable reason for enhanced production of $285 \mathrm{H}_{2} \mathrm{O}_{2}$ followed by higher $\mathrm{OH}^{-}$load in plant cell. $\mathrm{H}_{2} \mathrm{O}_{2}$ with its involvement as a substrate in GPX 286 reaction act as lignin precursor and facilitate cross-linking of cell wall materials. Moreover, over 287 expression of $N H X 1$ gene at $400 \mathrm{mM}$ reduced hyper-ionic $\mathrm{Na}^{+}$stress via its transport to vacuole.

288 On the other hand, at $800 \mathrm{mM}$ the activation of PAL accompanied by greater phenol 289 accumulation resulted in lower ROS due to involvement of NADPH for phenol synthesis and its 290 photo protective role. However, higher phenol accumulation resulting from greater stimulation of 291 PAL at $800 \mathrm{mM}$ salt stress provided a mechanism to reduce the energy imbalance between that 292 received and processed by plant by dissipating it as either as heat or fluorescence or both. Present 293 study judiciously unfolds the physico-biochemical and molecular mechanism behind the salt 294 stress response in $A$. auriculiformis and affirms the significance of this tree species for uplifting 295 livelihood and sustenance of salinity affected coastal areas. 
297 'Conflict of Interest: none declared'.

\section{Acknowledgement}

299 Authors would like to acknowledge Bidhan Chandra Krishi Viswavidyalaya (BCKV) for 300 providing basic support to carry out the research.

\section{Authors' Contributions}

SP and JB conceptualized the study, DG, KP implemented and executed the experiment, DG, JB and KP collected the data, AD and SP carried out data analysis and interpretation and SP, JB, KP and $\mathrm{AD}$ composed the manuscript.

\section{References}

306

307

308

309

1. Gupta B and Huang B. Mechanism of salinity tolerance in plants: physiological, biochemical, and molecular characterization. Int $\mathrm{J}$ Genomics 2014; 1-18. http://dx.doi.org/10.1155/2014/701596.

2. Chaparzadeh N, D'Amico ML, Khavari-Nejad RA, Izzo R, Navari-Izzo F. Antioxidative responses of Calendula officinalis under salinity conditions. Plant Physiol Biochem. 2004; 42(9): 695-701. DOI: 10.1016/j.plaphy.2004.07.001 PMID: 15474374

3. Hernández I and Van BF. Opinion on the possible role of flavonoids as energy escape valves: novel tools for nature's Swiss army knife? Plant Sci. 2010; 179(4): 297-301. https://doi.org/10.1016/j.plantsci.2010.06.001

4. Asada K. Production and scavenging of reactive oxygen species in chloroplasts and their functions. Plant Physiol. 2006; 141(2): 391-396. DOI: 10.1104/pp.106.082040 PMID: 16760493 
318 5. Takahashi S, Murata N. How do environmental stresses accelerate photoinhibition? Trends

319 Plant Sci. 2008; 13(4):178-182. DOI: 10.1016/j.tplants.2008.01.005 PMID: 18328775

320 6. Gill SS and Tuteja N. Reactive oxygen species and antioxidant machinery in abiotic stress

321 tolerance in crop plants. Plant Physiol. Biochem. 2010; 48(12): 909-930. DOI:

322 10.1016/j.plaphy.2010.08.016 PMID: 20870416

323 7. Amor NB, Jiménez A, Megdiche W, Lundqvist M, Sevilla F, Abdelly C. Response of 324 antioxidant systems to $\mathrm{NaCl}$ stress in the halophyte Cakile maritima. Physiol. Plant. 2006; 126(3): 446-457. https://doi.org/10.1111/j.1399-3054.2006.00620.x

326 8. Colla G, Rouphael Y, Jawad R, Kumar P, Rea E, Cardarelli M. The effectiveness of grafting to 327 improve $\mathrm{NaCl}$ and $\mathrm{CaCl} 2$ tolerance in cucumber. Sci. Hortic. 2013; 164: 380-391. 328 https://doi.org/10.1016/j.scienta.2013.09.023

329 9. Shao H, Wang H, Tang X. NAC transcription factors in plant multiple abiotic stress responses: 330 progress and prospects. Front. Plant Sci. 2015; 6:902. DOI: 10.3389/fpls.2015.00902 PMID: $331 \quad 26579152$

332

10. Zhou H, Lin H, Chen S, Becker K, Yang Y, Zhao J, Kudla J, Schumaker KS, Guo Y. Inhibition of the Arabidopsis salt overly sensitive pathway by 14-3-3 proteins. Plant Cell. 2014; 26(3): 1166-1182. DOI: 10.1105/tpc.113.117069 PMID: 24659330

11. Yang Y, Guo Y. Unraveling salt stress signaling in plants. J. Integr. Plant Biol. 2018; 60(9):796-804. DOI: 10.1111/jipb.12689 PMID: 29905393

12. Barragán V, Leidi EO, Andrés Z, Rubio L, De Luca A, Fernández JA, Cubero B, Pardo JM. Ion exchangers NHX1 and NHX2 mediate active potassium uptake into vacuoles to regulate 
cell turgor and stomatal function in Arabidopsis. Plant Cell. 2012; 24(3): 1127-1142. DOI: 10.1105/tpc.111.095273 PMID: 22438021

13. Rahman MM, Rahman MA, Miah MG, Saha SR, Karim MA, Mostofa MG. Mechanistic insight into salt tolerance of Acacia auriculiformis: the importance of ion selectivity, osmoprotection, tissue tolerance, and $\mathrm{Na}+$ exclusion. Front. Plant Sci. 2017; 8: 155. DOI: 10.3389/fpls.2017.00155 PMID: 28421081

14. Chowdhury Q, Ishiguri F, Iizuka K, Hiraiwa T, Matsumoto K, Takashima Y, Yokota S, Yoshizawa N. Wood property variation in Acacia auriculiformis growing in Bangladesh. Wood and Fiber Sci. 2009; 41(4): 359-365.

15. Patel AD, Jadeja H, Pandey AN. Effect of salinization of soil on growth, water status and nutrient accumulation in seedlings of Acacia auriculiformis (Fabaceae). J. Plant Nutr. 2010; 33(6): 914-932. https://doi.org/10.1080/01904161003669939

16. Alla MN and Hassan NM. Changes of antioxidants levels in two maize lines following atrazine treatments. Plant Physiol. Biochem. 2006; 44(4):202-210. DOI: 10.1016/j.plaphy.2006.05.004 PMID: 16777423

17. Rosler J, Krekel F, Amrhein N, Schmid J. Maize phenylalanine ammonia-lyase has tyrosine ammonia-lyase activity. Plant physiol. 1997; 113(1):175-179. DOI: 10.1104/pp.113.1.175 PMID: 9008393

18. Vinson JA, Hao Y, Su X, Zubik L. Phenol antioxidant quantity and quality in foods: vegetables. J. Agric. Food Chem. 1998; 46(9):3630-3634. 
359

360

361

362

363

364

365

366

367

368

369

370

371

372

373 374

375

19. Žilić S, Mogol BA, Akıllığlu G, Serpen A, Babić M, Gökmen V. Effects of infrared heating on phenolic compounds and Maillard reaction products in maize flour. J. Cereal Sci. 2013 ;58(1):1-7. https://doi.org/10.1016/j.jcs.2013.05.003

20. Tausz M, Wonisch A, Grill D, Morales D, Jiménez MS. Measuring antioxidants in tree species in the natural environment: from sampling to data evaluation. J. Exp. Bot. 2003; 54(387):15051510. DOI: $10.1093 / \mathrm{jxb} / \mathrm{erg} 175$ PMID: 12759368

21. Thaipong K, Boonprakob U, Crosby K, Cisneros-Zevallos L, Byrne DH. Comparison of ABTS, DPPH, FRAP, and ORAC assays for estimating antioxidant activity from guava fruit

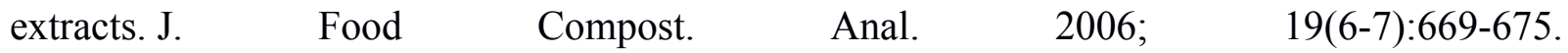
https://doi.org/10.1016/j.jfca.2006.01.003

22. Banerjee J, Das N, Dey P, Maiti MK. Transgenically expressed rice germin-like protein1 in tobacco causes hyper-accumulation of $\mathrm{H}_{2} \mathrm{O}_{2}$ and reinforcement of the cell wall components. Biochem. Biophys. Res. Commun. 2010; 402(4): 637-643. DOI: 10.1016/j.bbrc.2010.10.073 PMID: 20971065

23. Van Breusegem F, Dat J.F. Reactive oxygen species in plant cell death. Plant physiol. 2006; 141(2): 384-390.

24. Li Z, Wakao S, Fischer BB, Niyogi KK. Sensing and responding to excess light. Annu. Rev. Plant Biol. 2009; 60:239-260. DOI: 10.1146/annurev.arplant.58.032806.103844 PMID: 19575582

25. Parida AK, Das AB, Mittra B. Effects of salt on growth, ion accumulation, photosynthesis and leaf anatomy of the mangrove, Bruguiera parviflora. Trees 2004; 18(2):167-174. DOI: $10.1007 / \mathrm{s} 00468-003-0293-8$ 
381 26. Jalali-e-Emam, SMS, Alizadeh B, Zaefizadeh M, Zakarya RA, Khayatnezhad M. Superoxide

382 dismutase (SOD) activity in $\mathrm{NaCl}$ stress in salt-sensitive and salt-tolerance genotypes of Colza

383 (Brassica napus L.). Middle East J. Sci. Res. 2011; 7: 7-11.

384 27. Chawla S, Jain S, Jain V. Salinity induced oxidative stress and antioxidant system in salt385 tolerant and salt-sensitive cultivars of rice (Oryza sativa L.). J Plant Biochem.

386 Biotechnol. 2013; 22(1): 27-34. DOI: 10.1007/s00709-011-0365-3 PMID: 22194018

387 28. Gossett DR, Millhollon EP, Lucas M. Antioxidant response to NaCl stress in salt-tolerant and salt-sensitive cultivars of cotton. Crop Sci.1994; 34(3): 706-714. doi:10.2135/cropsci1994.0011183X003400030020x

390 391

392 393 394 395 396

29. Mittal M, Flora SJS. Vitamin E supplementation protects oxidative stress during arsenic and fluoride antagonism in male mice. Drug Chem Toxicol. 2007; 30(3): 263-281.

30. Rivero RM, Ruiz JM, García PC, López-Lefebre LR, Sánchez E, Romero L. Response of oxidative metabolism in watermelon plants subjected to cold stress. Funct Plant Biol. 2002; 29(5): 643-648.

31. Kalir A, Omri G, Poljakoff-Mayber A. Peroxidase and catalase activity in leaves of Halimione portulacoides exposed to salinity. Physiol Plantarum. 1984; 62(2): 238-244.

32. Kim JH, Campbell BC, Mahoney N, Chan KL, May GS. Targeting antioxidative signal transduction and stress response system: control of pathogenic Aspergillus with phenolics that inhibit mitochondrial function. J. Appl. Microbiol. 2006; 101(1): 181-189. DOI: 10.1111/j.1365-2672.2006.02882.x PMID: 16834605 
401

402

403

404

405

406

407

408

409

410

33. Giorgi A, Mingozzi M, Madeo M, Speranza G, Cocucci M. Effect of nitrogen starvation on the phenolic metabolism and antioxidant properties of yarrow (Achillea collina Becker ex Rchb.). Food Chem. 2009; 114(1), 204-211. https://doi.org/10.1016/j.foodchem.2008.09.039

34. Lim JH, Park KJ, Kim BK, Jeong JW, Kim HJ. Effect of salinity stress on phenolic compounds and carotenoids in buckwheat (Fagopyrum esculentum M.) sprout. Food Chem. 2012; 135(3): 1065-1070. DOI: 10.1016/j.foodchem.2012.05.068 PMID: 22953825

35. Yan K, Zhao S, Bian L, Chen X. Saline stress enhanced accumulation of leaf phenolics in honeysuckle (Lonicera japonica Thunb.) without induction of oxidative stress. Plant Physiol. Biochem. 2017; 112:326-334. DOI: 10.1016/j.plaphy.2017.01.020 PMID: 28131061

36. Yuan G, Wang X, Guo R, Wang Q. Effect of salt stress on phenolic compounds, glucosinolates, myrosinase and antioxidant activity in radish sprouts. Food Chem. 2010; 121(4):1014-1019. https://doi.org/10.1016/j.foodchem.2010.01.040

37. Navarro JM, Flores P, Garrido C, Martinez V. Changes in the contents of antioxidant compounds in pepper fruits at different ripening stages, as affected by salinity. Food Chem. 2006; 96(1):66-73. DOI: 10.1016/j.foodchem.2005.01.057

38. Yan K, Cui M, Zhao S, Chen X, Tang X. Salinity stress is beneficial to the accumulation of chlorogenic acids in honeysuckle (Lonicera japonica Thunb.). Front. Plant Sci.2016; 7: 1563. DOI: 10.3389/fpls.2016.01563 PMID: 27803710

39. Ksouri R, Megdiche W, Debez A, Falleh H, Grignon C, Abdelly C. Salinity effects on polyphenol content and antioxidant activities in leaves of the halophyte Cakile maritima. Plant Physiol. Biochem. 2007; 45(3-4): 244-249. DOI: 10.1016/j.plaphy.2007.02.001 PMID: 17408958 
423

424

425

426

427

428

429

430

431

432

433

434

435

436

437

438

439

440

441

442

40. Conrad AO, Yu J, Staton ME, Audergon JM, Roch G, Decroocq V, Knagge K, Chen H, Zhebentyayeva T, Liu Z, Dardick C, Nelson CD, Abbott AG. Association of the phenylpropanoid pathway with dormancy and adaptive trait variation in apricot (Prunus armeniaca). Tree physiol. 2019:39(7):1136-1148. doi: 10.1093/treephys/tpz053.

41. Hernandez JA, Jimenez A, Mullineaux P, Sevilia F. Tolerance of pea (Pisum sativum L.) to long-term salt stress is associated with induction of antioxidant defenses. Plant Cell Environ. 2000.23(8): 853-862. https://doi.org/10.1046/j.1365-3040.2000.00602.x

42. Banerjee J, Gantait S, Maiti MK. Physiological role of rice germin-like protein 1 (OsGLP1) at early stages of growth and development in indica rice cultivar under salt stress condition. Plant Cell Tissue Organ Cult. 2017; 131(1): 127-137. DOI: 10.1007/s11240-017-1270-z

43. Moshaei MR, Nematzadeh GA, Askari H, Nejad ASM. Quantitative gene expression analysis of some sodium ion transporters under salinity stress in Aeluropus littoralis. Saudi J Biol Sci. 2014; 21(5):394-399. DOI: 10.1016/j.sjbs.2014.05.001 PMID: 25313273

44. Duncan DB. Multiple range and multiple F tests. Biometrics. 1955; 11(1): 1-42. 
Table. 1: Mean value of 15 phenolic compounds detected under various salt concentration in $A$.

\begin{tabular}{|c|c|c|c|c|c|c|}
\hline \multirow{2}{*}{$\begin{array}{l}\text { Sl } \\
\text { No. }\end{array}$} & \multirow[t]{2}{*}{ Parameter } & \multicolumn{5}{|c|}{ Treatment } \\
\hline & & A0 & A200 & $\mathrm{A} 400$ & A600 & A800 \\
\hline \multicolumn{7}{|c|}{ 1. Hydroxyl Benzoic Acid ( $\mu \mathrm{g} / \mathrm{g}) \mathrm{DW}$} \\
\hline a. & Gallic Acid & $558.46 \mathrm{c}$ & $556.64 \mathrm{c}$ & $560.14 \mathrm{c}$ & $578.44 \mathrm{~b}$ & $606.88 \mathrm{a}$ \\
\hline b. & Proto catechuic & $164.14 \mathrm{~d}$ & $218.76 \mathrm{c}$ & $222.78 \mathrm{c}$ & $238.72 \mathrm{~b}$ & $284.52 \mathrm{a}$ \\
\hline c. & P.Oh. Benzoic & $36.13 \mathrm{~d}$ & $39.35 \mathrm{~d}$ & $44.91 \mathrm{c}$ & $56.78 \mathrm{~b}$ & $76.12 \mathrm{a}$ \\
\hline d. & Vanillic Acid & $88.23 \mathrm{~d}$ & $102.55 \mathrm{c}$ & $154.35 \mathrm{~b}$ & $156.98 \mathrm{~b}$ & $171.35 \mathrm{a}$ \\
\hline & Total & $846.96 \mathrm{e}$ & $917.3 \mathrm{~d}$ & $982.18 \mathrm{c}$ & 1030.92 b & 1138.87 a \\
\hline \multicolumn{7}{|c|}{ 2. Hydroxy Cinnamic Acid $(\mu g / g) D W$} \\
\hline a. & Caffeic Acid & $48.54 \mathrm{~d}$ & $52.76 \mathrm{~d}$ & $60.58 \mathrm{c}$ & $72.67 \mathrm{~b}$ & $81.37 \mathrm{a}$ \\
\hline $\mathrm{b}$. & Cinnamic Acid & $2.17 \mathrm{c}$ & $2.76 \mathrm{~b}$ & $3.69 \mathrm{a}$ & $3.57 \mathrm{a}$ & $2.04 \mathrm{~d}$ \\
\hline c. & P. Coumaric & $2.37 \mathrm{e}$ & $3.14 \mathrm{~d}$ & $6.68 \mathrm{a}$ & $5.07 \mathrm{~b}$ & $4.55 \mathrm{c}$ \\
\hline d. & $\begin{array}{l}\text { Cholorogenic } \\
\text { Acid }\end{array}$ & $106.34 \mathrm{~d}$ & $124.67 \mathrm{c}$ & $154.32 \mathrm{~b}$ & $161.76 \mathrm{~b}$ & $174.65 \mathrm{a}$ \\
\hline e. & Ferulic Acid & $6.98 \mathrm{a}$ & $5.05 \mathrm{c}$ & $6.21 \mathrm{~b}$ & $4.66 \mathrm{~d}$ & $3.38 \mathrm{e}$ \\
\hline & Total & $166.4 \mathrm{e}$ & $188.38 \mathrm{~d}$ & $231.48 \mathrm{c}$ & $247.73 \mathrm{~b}$ & 265.99 a \\
\hline \multicolumn{7}{|c|}{ 3. Flavonoids $(\mu \mathrm{g} / \mathrm{g}) \mathrm{DW}$} \\
\hline a. & Myricetin & $49.77 \mathrm{~d}$ & $88.73 \mathrm{c}$ & $118.44 \mathrm{~b}$ & $132.96 \mathrm{a}$ & $138.34 \mathrm{a}$ \\
\hline b. & Luteolin & $82.08 \mathrm{c}$ & $77.98 \mathrm{c}$ & $122.68 \mathrm{~b}$ & $116.96 \mathrm{~b}$ & $132.12 \mathrm{a}$ \\
\hline c. & Kaemferol & $78.22 \mathrm{~d}$ & $108.55 \mathrm{c}$ & $117.71 \mathrm{~b}$ & $114.78 \mathrm{~b}$ & $126.29 \mathrm{a}$ \\
\hline d. & Rutin & $\begin{array}{c}\text { Not } \\
\text { detected }\end{array}$ & $\begin{array}{c}\text { Not } \\
\text { detected }\end{array}$ & $\begin{array}{c}\text { Not } \\
\text { detected }\end{array}$ & $\begin{array}{c}\text { Not } \\
\text { detected }\end{array}$ & Not detected \\
\hline e. & Quercetin & $74.56 \mathrm{e}$ & $99.54 \mathrm{~d}$ & $132.11 \mathrm{c}$ & $146.76 \mathrm{~b}$ & $156.67 \mathrm{a}$ \\
\hline $\mathrm{f}$. & Catechin & $1696.12 \mathrm{e}$ & $1743.66 \mathrm{~d}$ & $1858.62 \mathrm{c}$ & $1906.77 \mathrm{~b}$ & $1996.77 \mathrm{a}$ \\
\hline g. & Apigenin & $74.58 \mathrm{e}$ & $90.43 \mathrm{~d}$ & $108.45 \mathrm{c}$ & $128.43 \mathrm{~b}$ & $148.32 \mathrm{a}$ \\
\hline & Total & 2055.33 & $2208.89 c$ & 2458.01b & $2546.66 b$ & 2698.51a \\
\hline & Grand Total & $3068.69 \mathrm{e}$ & 3314.57d & $36791.67 c$ & 3825.31b & 4103.37a \\
\hline
\end{tabular}




\section{Figure legends}

451 Fig. 1. Effect of salt stress on enzymatic antioxidants in A. auriculiformis. (A) Superoxide 452 dismutase (SOD) activity in leaf (phyllode) tissue of untreated (Control) and indicated amount of $453 \mathrm{NaCl}$ stressed seedlings. (B) Catalase (CAT) activity in leaf (phyllode) tissue of untreated 454 (Control) and indicated amount of $\mathrm{NaCl}$ stressed seedlings. (C) Phenylalanine ammonia-lyase 455 (PAL) activity in the leaf (phyllode) tissue of untreated (Control) and indicated amount of $\mathrm{NaCl}$ 456 stressed seedlings. Data represent mean \pm SD having $\mathrm{n}=3$.

457 Fig. 2. Effect of salt stress on non-enzymatic antioxidants, PAL activity and total antioxidant activity in A. auriculiformis. (A) Guaiacol peroxidase (GPX) activity in leaf (phyllode) tissue of untreated (Control) and indicated amount of $\mathrm{NaCl}$ stressed seedlings. Total phenol (B) and total thiol (C) content in the leaf (phyllode) tissue of untreated (Control) and indicated amount of $\mathrm{NaCl}$ stressed seedlings.

Fig. 3. Retention time of 16 phenolic compounds (Retention time gallic acid:2.063, protocatechuic acid:2.774, chlorogenic acid:3.174, catechin:3.357, p-hydroxybenzoic acid:4.217, caffeic acid:4.75, vanillic acid:4.929, p-comaric acid:8.512, ferulic acid:10.837, rutin:11.291, myricetin:16.251, luteolin:18.266, quercetin: 18.376 cinnamic acid:18.836, apigenin:19.761, kaemferol:20.059 min) detected in Acacia auriculiformis.

467 Fig. 4. Total antioxidant properties under DPPH and FRAP assay in the leaf (phyllode) tissue of 468 untreated (Control) and indicated amount of $\mathrm{NaCl}$ stressed seedlings of A. auriculiformis. Data represent mean \pm SD having $\mathrm{n}=3$.

Fig. 5. Morphological, anatomical and molecular changes in A. auriculiformis upon salt stress.

471 (A) Morphological study on A. auriculiformis seedlings after indicated amount of salt stress for 
47210 days along with deionized water treated control seedling. (B) Phloroglucinol staining of

473 transverse section of $A$. auriculiformis phyllode grown in control and indicated amount of salt

474 stressed condition for 10 days. Bar indicates $200 \mu \mathrm{m}$. (C) Transcript expression of $N H X 1$ in the

475 leaf tissue of control and $400 \mathrm{mM} \mathrm{NaCl}$ treated $A$. auriculiformis. Semi-quantitative RT-PCR of

476 control and $400 \mathrm{mM} \mathrm{NaCl}$ treated A. auriculiformis seedlings using Actin as internal control. (D)

477 The relative expression of $N H X 1$ gene (calculated using ImajeJ software analysis taking Actin

478 gene expression as loading control) in control and $400 \mathrm{mM} \mathrm{NaCl}$ treated A. auriculiformis

479 seedlings. Values are means \pm SD with $n=3$

480 Fig. 6. Biochemical cross-talk in A. auriculiformis under salt stress. Proposed model depicts the

481 involvement of various enzymatic and non-enzymatic antioxidants under control, $400 \mathrm{mM} \mathrm{NaCl}$

482 stress and $800 \mathrm{mM} \mathrm{NaCl}$ stress for the cross-linking of cell wall components. Red and blue arrow

483 indicates enhanced and retarded activity, respectively. 




Figure 


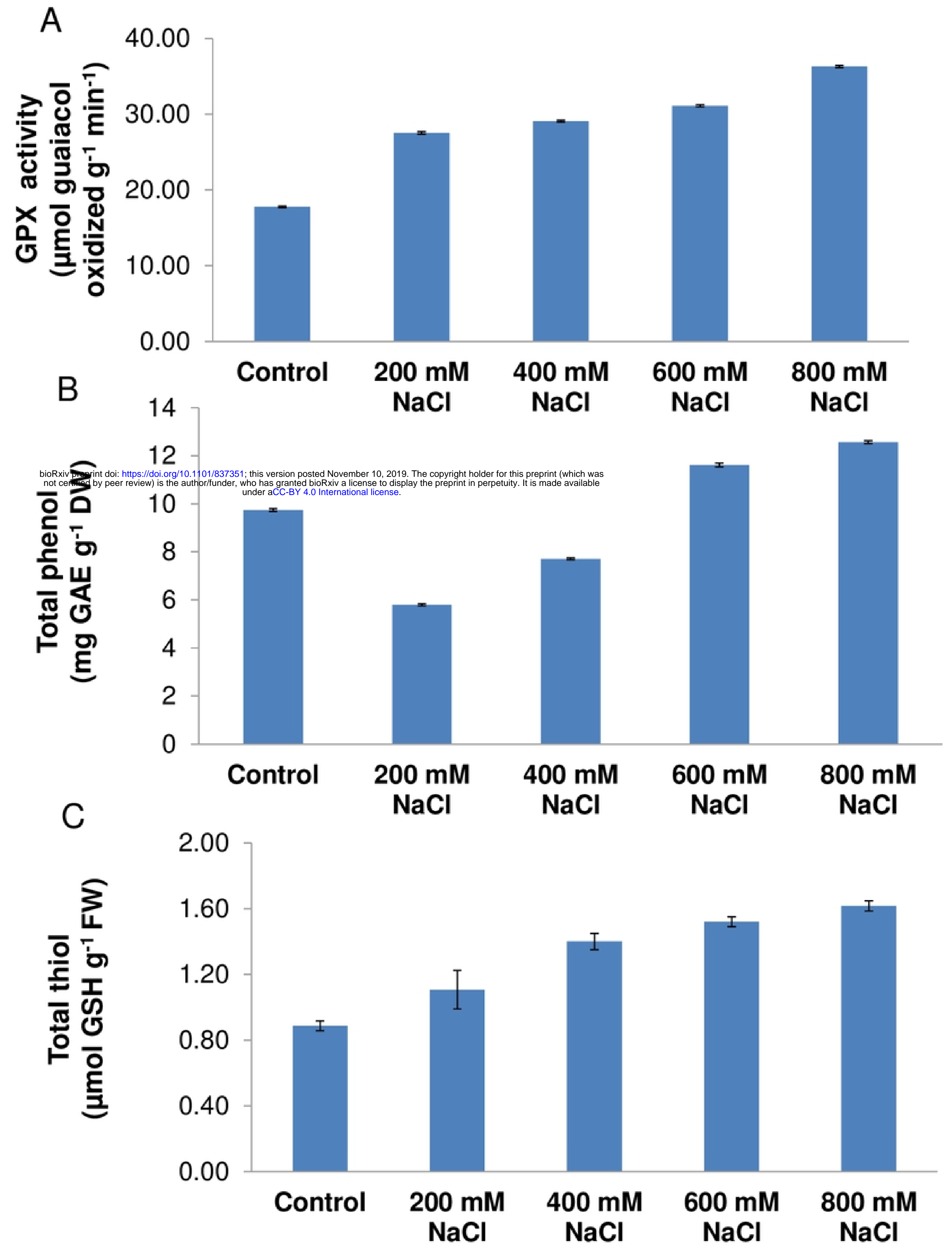

Figure 


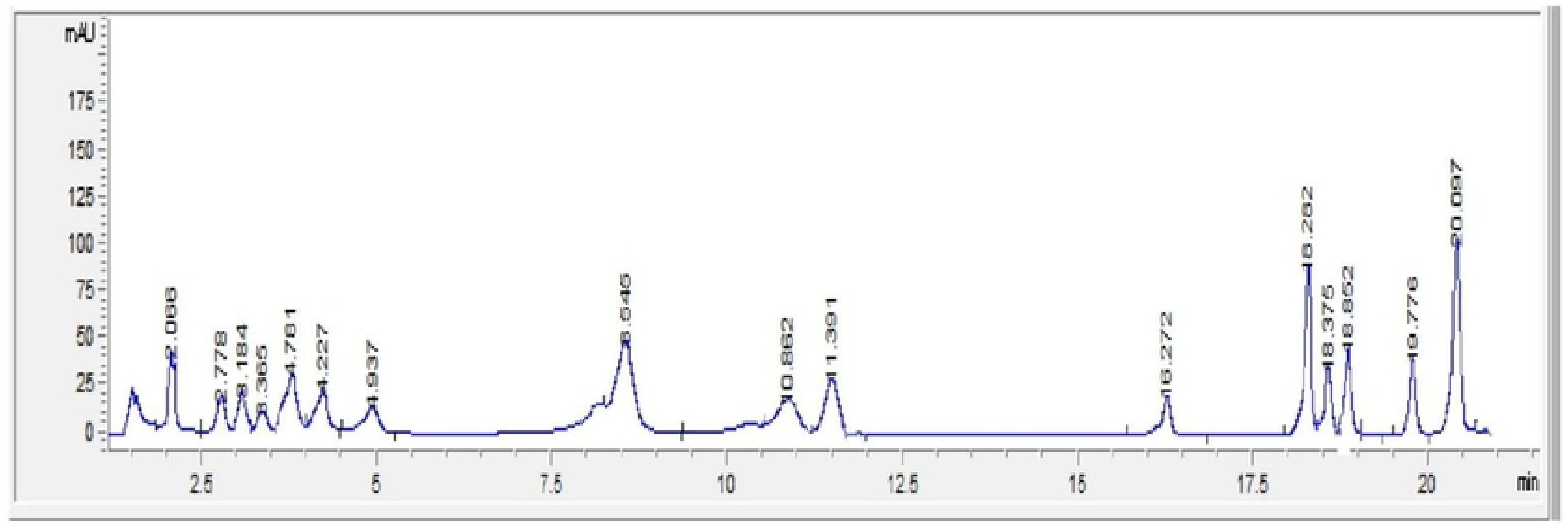

Figure 


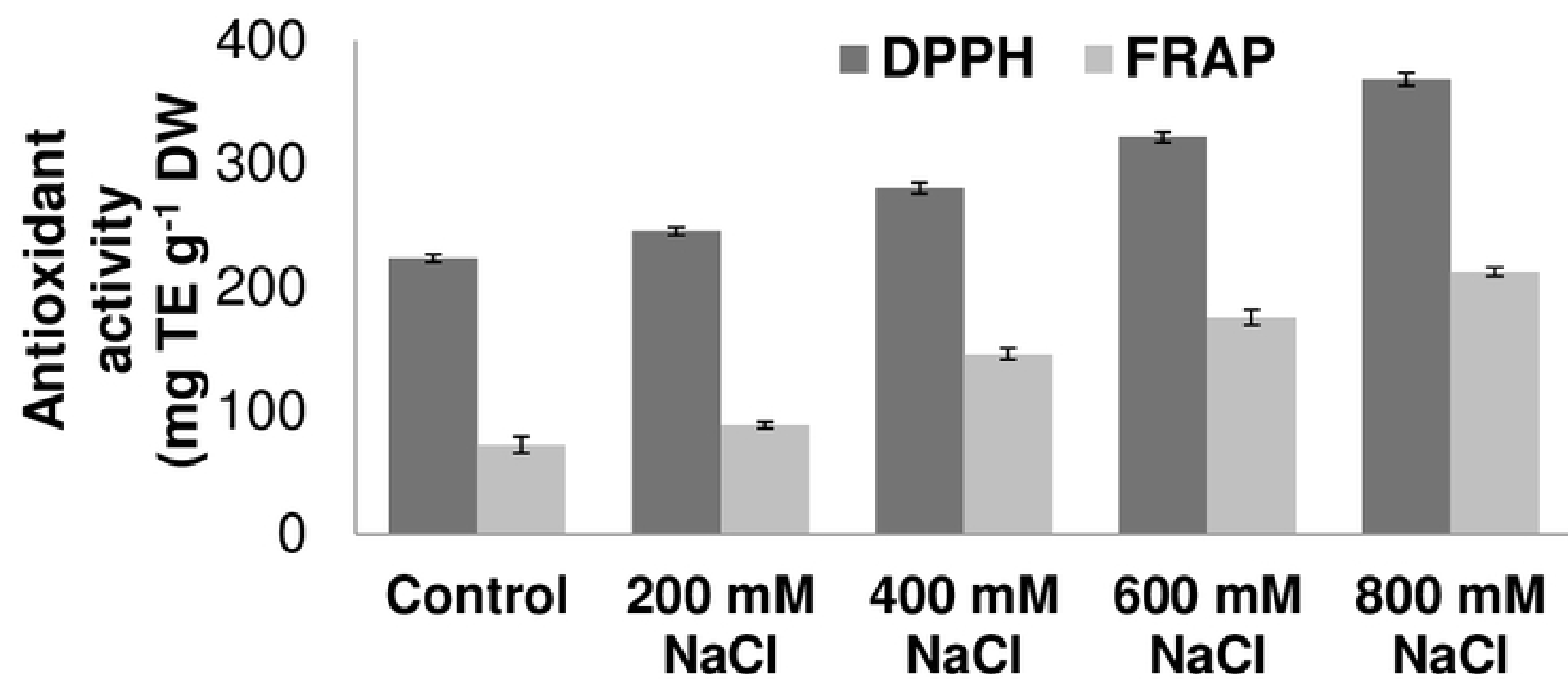

Figure 
